\title{
Assessment of Mothers' Knowledge toward Cesarean Section Complications at the Hospitals in Baghdad City Hospitals
}

\author{
Buthainah Basheer Saleh ${ }^{1}$, Wissam I. Wardia ${ }^{2}$ \\ ${ }^{1}$ Lecturer, Collage of Nursing-Al-Bayan University, \\ ${ }^{2}$ Assistant Lecturer, Collage of Nursing-Al-Bayan University
}

\begin{abstract}
Background: Cesarean section is one of the most frequently performed major abdominal surgeries and carries the risk of infection, including local wounds, pelvic, respiratory tract, and urinary tract infections, as well as lung emboli, venous thrombosis, and complications of anesthesia.

Objective: The study aimed to assess mothers' knowledge toward complications of cesarean section and to find out the relationship between mothers' knowledge and their demographic characteristics such as (age, level of education, and mulitiparacesarean section).

Methodology: A descriptive (cross- section) study design was conducted on (100) mothers with cesarean section in the maternal ward. (The data were collected by the investigator, fill the questionnaire formats by interview technique and fill it by the investigator). Questionnaire form was constructed for the purpose of the study. It consists of two parts which were dealing with the demographic characteristics of mothers and the mothers' knowledge towards cesarean section complications. The data collection reliability of the questionnaire was determined through internal consistency. Content validity of the questionnaire was determined through panel of experts. Data were analyzed through descriptive and statistical approach (frequency and percentage, and chi-square) by Socioeconomic Package for Social Science approach Version 16.
\end{abstract}

Results: The finding of the study demonstrated one result about the knowledge of mothers there was accepted statistical percentage between mothers' knowledge and their demographic characteristics such as (age, level of education, and multipara cesarean section).

Keywords: Assessment, Cesarean Section, Complications, Hospitals.

\section{Introduction}

Cesarean section (CS) is one of the most frequently performed major abdominal surgeries. Despite a lack of upsurge in obstetric emergencies, the rate of CS has increased in many parts of the world, reaching higher than $50 \%$ in some countries. ${ }^{(1-3)}$ Most of these CS surgeries are performed without any medical indication and some are cesarean delivery on mother's request (CDMR). (4) The world incidence of CDMR is estimated to be $8-14 \%$ of all cesarean deliveries ${ }^{(5)}$. In order to prevent the dangers of vaginal delivery, the idea of elective CS in full-term pregnancy attracted the media's attention about 20 years ago. ${ }^{(6)}$ Since then, there have been serious discussions about performing CDMR in full- term pregnancies. ${ }^{(7)}$ Although recent studies have shown that the risk of planned CS and planned vaginal delivery in the short term are low and similar, in subsequent pregnancies, the risk will be higher in a mother who has had a previous CS. ${ }^{(8,9}$ and ${ }^{10)}$ Like other surgical operations, CS carries the risk of infection, including local wounds, pelvic, respiratory tract, and urinary tract infections, as well as lung emboli, venous thrombosis, and complications of anesthesia. Thus morbidity and mortality rates are higher in CS compared to normal vaginal delivery (NVD) in both mother and child. ${ }^{(11)}$ In addition, studies show that financial burden of repeated CS, including duration of hospitalization, drugs used, and their complications, are significantly greater as 
compared to NVD. ${ }^{(12)}$ Other complications of CS are the increased risk of placental adherence and uterine rupture in subsequent pregnancies, intensive care admission, hysterectomy, problems with subsequent fertility (e.g., reduced fertility, ectopic pregnancy, miscarriage), and increased risks of fetal and neonatal mortality. ${ }^{(13)}$

\section{Methodology}

Descriptive study design was conducted on (100) mothers having multipara delivery, data collection started from $20^{\text {th }}$ February 2016 to $20^{\text {th }}$ April 2016 achieve the objectives of the study. The study was carried out by Baghdad Teaching Hospital at medical city and Mohammed Bakeer Al- Hakeem Teaching Hospital. Non- probability (purposive) sample of (100) mothers multipara cesarean section. The questionnaire was designed and constructed by the investigator to measure the variable underlying the study. A questionnaire was consisted of two parts :(1) demographical information includes items such as (mothers' age, mothers' multipara cesarean deliveries) and the complications effects on the mothers. The second part it comprised of structured (16) items concerning mothers' knowledge toward complications of cesarean section on her health. Items related to the knowledge of sample under study rated according to 3 points rating scale(I know, uncertain and don't know)data were collected through the use of questionnaire format and, means of an interview with mothers who have multipara cesarean section in maternity ward. A pilot studies was conducted on (10) mothers who have mulipara cesarean section selected from Nurse Home Hospital at 15 February 2016, and the result by Split Half : $(r=0.80)$. Data analyzed through the application of statistical procedure which may assist for the determination of the study finding.

\section{Results}

\section{Mothers Age Groups and their Multipara Cesarean Section}

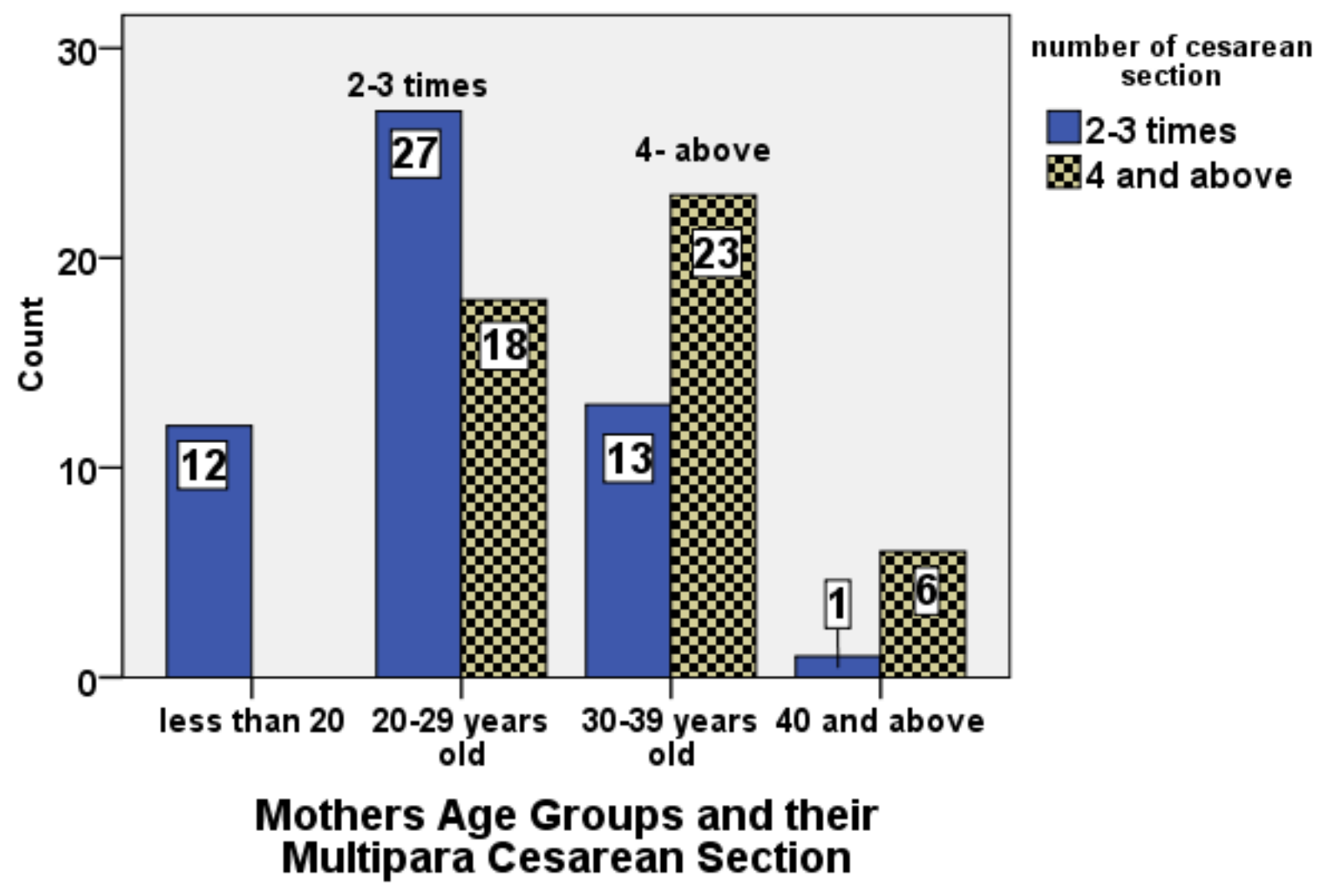

Figure (1) Association between Maltipara Caesarian Section of the Study Sample and their Age 
Mothers Level of Education and their Multipara Cesarean ...

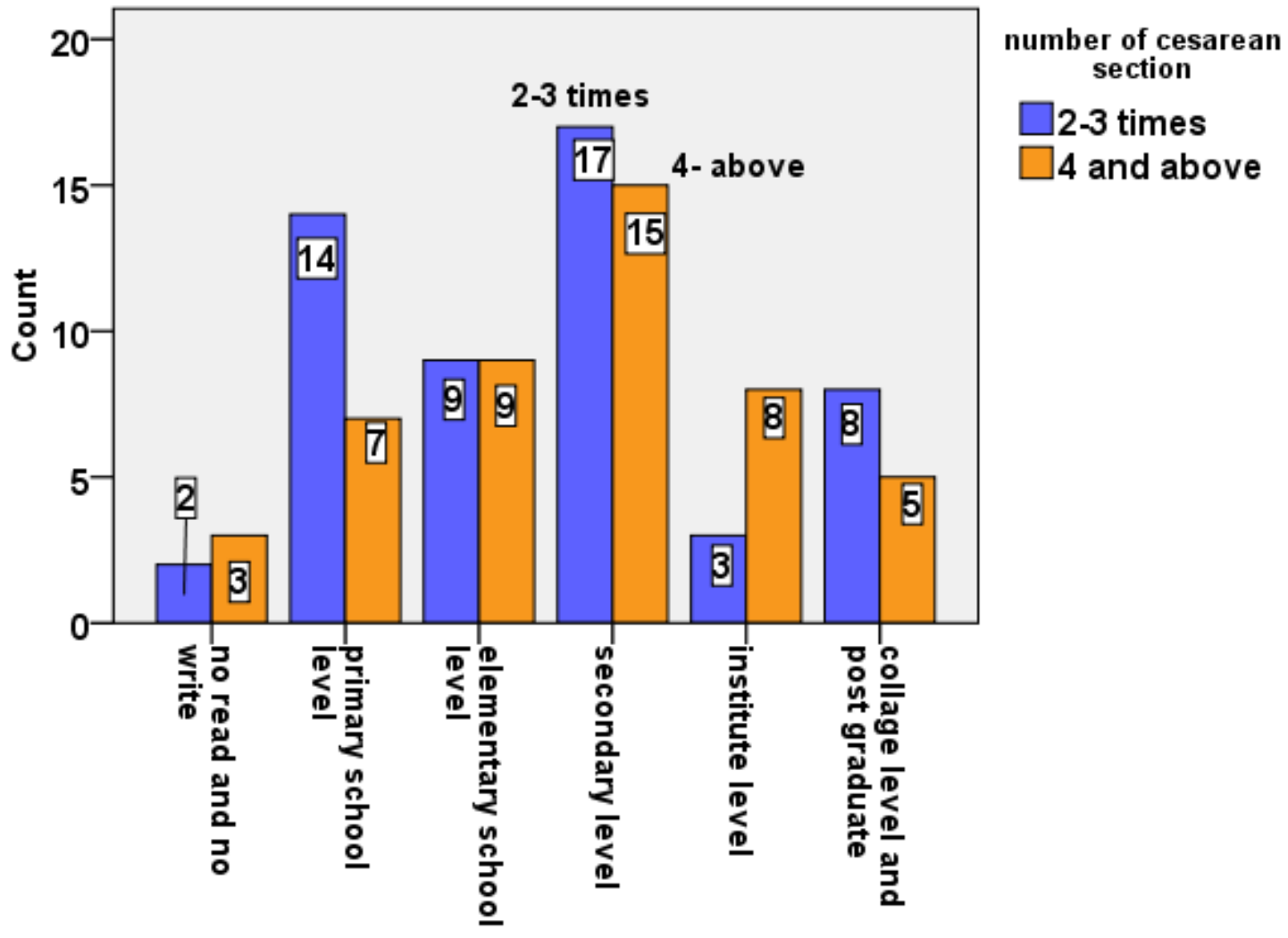

mothers level of education

Figure (2): Association between Maltipara Cesarean Section of the Study Sample and their Educational Level

Table (1): Distribution of Study Sample General Information

\begin{tabular}{|c|c|c|c|c|}
\hline \multirow{2}{*}{$\begin{array}{c}\text { No. } \\
1-\end{array}$} & \multicolumn{3}{|c|}{ Variables } & \multirow{2}{*}{ Total } \\
\hline & Mothers' Age Group & $* \mathbf{F}$. & $* * \%$ & \\
\hline $1-1$ & Less than 20 years & 12 & 12 & \multirow{4}{*}{$100(100 \%)$} \\
\hline $1-2$ & 20-29 years old & 45 & 45 & \\
\hline $1-3$ & $30-39$ years old & 36 & 36 & \\
\hline $1-4$ & 40 and above years old & 7 & 7 & \\
\hline $2-$ & Mothers' Educational Level & *F. & $* * \%$ & Total \\
\hline $2-1$ & No Read and no Write & 5 & 5 & \multirow{6}{*}{$100(100 \%)$} \\
\hline $2-2$ & Primary Level & 21 & 21 & \\
\hline $2-3$ & Elementary Level & 18 & 18 & \\
\hline $2-4$ & Secondary Level & 32 & 32 & \\
\hline $2-5$ & Instituted Level & 11 & 11 & \\
\hline $2-6$ & Collage and Postgraduate Level & 13 & 13 & \\
\hline $3-$ & Mothers' Multipara Cesarean Section & *F. & $* * \%$ & Total \\
\hline $3-1$ & 2-3 times of Caesarian Section & 53 & 53 & \multirow{2}{*}{$100(100 \%)$} \\
\hline $3-2$ & 4- and above times of Caesarian Section & 47 & 47 & \\
\hline
\end{tabular}

$* \mathrm{~F} .=$ Frequency, $* * \%=$ Percent 
This table shows that more than one third percent (45\%) at mothers' age group (20-29 years old), while one third percent (32\%) for secondary level of education, and more than half percent of the study sample (53\%) have (2-3) times cesarean section.

Table (2) Distribution of the Mothers' Knowledge toward Complications of Cesarean Section

\begin{tabular}{|c|c|c|c|c|c|c|c|}
\hline \multirow{2}{*}{ No. } & \multirow{2}{*}{ Complication Effect on Mothers' Health } & \multicolumn{2}{|c|}{ I Know } & \multicolumn{2}{|c|}{ Uncertain } & \multicolumn{2}{|c|}{ Don't Know } \\
\hline & & $* \mathbf{F}$. & $* * \%$ & $* \mathbf{F}$. & $* * \%$ & $* \mathbf{F}$. & $* * \%$ \\
\hline $1-$ & Delayed healing wound after the operation & 89 & 89 & 9 & 9 & 2 & 2 \\
\hline $2-$ & Early bleeding after the operation ( 1 day -14 days) & 53 & 53 & 28 & 28 & 19 & 19 \\
\hline $3-$ & Late bleeding after the operation ( 15 day - 40 days) & 21 & 21 & 32 & 32 & 47 & 47 \\
\hline 4- & Bladder puncture during operation & 20 & 20 & 20 & 20 & 60 & 60 \\
\hline $5-$ & Respiratory tract infection as a result of anesthesia & 32 & 32 & 29 & 29 & 39 & 39 \\
\hline $6-$ & Weakness of a bowel movement after delivery & 48 & 48 & 28 & 28 & 24 & 24 \\
\hline $7-$ & Obesity and bulge the mother's abdomen & 61 & 61 & 24 & 24 & 15 & 15 \\
\hline $8-$ & Urinary tract infection & 63 & 63 & 12 & 12 & 25 & 25 \\
\hline 9- & Clotting blood in lungs, and Legs. & 30 & 30 & 25 & 25 & 45 & 45 \\
\hline $10-$ & Blood clots finally lead to death & 17 & 17 & 23 & 23 & 60 & 60 \\
\hline $11-$ & Inflammation of the uterus lining & 16 & 16 & 21 & 21 & 63 & 63 \\
\hline $12-$ & Laceration of the uterus wall & 12 & 12 & 27 & 27 & 61 & 61 \\
\hline $13-$ & Placenta progressing in the next pregnant & 15 & 15 & 21 & 21 & 64 & 64 \\
\hline $14-$ & Placenta permeation in the next pregnant & 15 & 15 & 21 & 21 & 64 & 64 \\
\hline $15-$ & Hysterectomy related to Placenta permeation & 13 & 13 & 20 & 20 & 67 & 67 \\
\hline 16- & Uterus explosion in the next deliveries & 27 & 27 & 29 & 29 & 44 & 44 \\
\hline
\end{tabular}

$* \mathrm{~F} .=$ Frequency,$* * \%=$ Percent

This table shows that most of the mothers were knowledgeable (89\%) about delayed healing wound after operation, more than half of them (53\%) knowing about bleeding after the operation, more than one third (48\%) weakness of bowel movement after delivery, more than one half $(61 \%$, and $63 \%)$ about obesity and bulge their abdomen, and about urinary tract infection. While in regard to other items mother have no information about them.

Table (3) Association between Mothers' Knowledge toward Complications of Cesarean Section and their Age

\begin{tabular}{|c|c|c|c|c|c|c|c|c|c|c|c|c|c|c|}
\hline \multirow[b]{3}{*}{ No. } & \multirow{3}{*}{$\begin{array}{l}\text { Mothers' Knowledge toward } \\
\text { Complications of Cesarean } \\
\text { Section }\end{array}$} & \multicolumn{12}{|c|}{ Mothers' Age Groups } & \multirow[b]{3}{*}{ p-Value } \\
\hline & & \multicolumn{3}{|c|}{ Less than 20} & \multicolumn{3}{|c|}{ 20-29 } & \multicolumn{3}{|c|}{ 30-39 } & \multicolumn{3}{|c|}{40 and above } & \\
\hline & & $\underline{\underline{\Xi}}$ & 竞 & 咅言 & $\underline{\Xi}$ & 竞 & 䓂言 & בְ & 竞 & 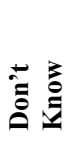 & ב & 芯 & $\begin{array}{l}\overrightarrow{0} \\
0\end{array}$ & \\
\hline 1 & $\begin{array}{l}\text { Delayed healing wound after } \\
\text { the operation }\end{array}$ & 10 & 1 & 1 & 41 & 3 & 1 & 33 & 3 & 0 & 5 & 2 & 0 & 0.331 \\
\hline 2 & $\begin{array}{l}\text { Early bleeding after the } \\
\text { operation ( } 1 \text { day }-14 \text { days) }\end{array}$ & 4 & 3 & 5 & 23 & 14 & 8 & 19 & 11 & 6 & 7 & 0 & 0 & 0.096 \\
\hline 3 & $\begin{array}{l}\text { Late bleeding after the } \\
\text { operation ( } 15 \text { day-40 days) }\end{array}$ & 1 & 3 & 8 & 9 & 15 & 21 & 9 & 12 & 15 & 2 & 2 & 3 & 0.823 \\
\hline 4 & $\begin{array}{l}\text { Bladder puncture during } \\
\text { operation }\end{array}$ & 1 & 3 & 8 & 9 & 9 & 27 & 9 & 6 & 21 & 1 & 2 & 4 & 0.910 \\
\hline 5 & $\begin{array}{l}\text { Respiratory tract infection as a } \\
\text { result of anesthesia }\end{array}$ & 2 & 4 & 6 & 17 & 13 & 15 & 11 & 9 & 16 & 2 & 3 & 2 & 0.764 \\
\hline
\end{tabular}




\begin{tabular}{|c|c|c|c|c|c|c|c|c|c|c|c|c|c|c|}
\hline \multirow[b]{3}{*}{ No. } & \multirow{3}{*}{$\begin{array}{l}\text { Mothers' Knowledge toward } \\
\text { Complications of Cesarean } \\
\text { Section }\end{array}$} & \multicolumn{12}{|c|}{ Mothers' Age Groups } & \multirow[b]{3}{*}{ p-Value } \\
\hline & & \multicolumn{3}{|c|}{ Less than 20} & \multicolumn{3}{|c|}{ 20-29 } & \multicolumn{3}{|c|}{ 30-39 } & \multicolumn{3}{|c|}{40 and above } & \\
\hline & & ב & 芯 & 泀言 & 党 & 茜 & 节言 & 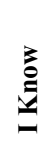 & 节 & 蒫 & ב & 这 & 䓂言 & \\
\hline 6 & $\begin{array}{l}\text { Weakness of a bowel } \\
\text { movement after delivery }\end{array}$ & 4 & 5 & 3 & 17 & 17 & 11 & 23 & 4 & 9 & 4 & 2 & 1 & 0.132 \\
\hline 7 & $\begin{array}{l}\text { Obesity and bulge the } \\
\text { mother's abdomen }\end{array}$ & 8 & 3 & 1 & 26 & 9 & 10 & 22 & 11 & 3 & 5 & 1 & 1 & 0.612 \\
\hline 8 & Urinary tract infection & 6 & 1 & 5 & 30 & 6 & 9 & 23 & 5 & 8 & 4 & 0 & 3 & 0.623 \\
\hline 9 & $\begin{array}{l}\text { Clotting blood in lungs, and } \\
\text { Legs. }\end{array}$ & 2 & 2 & 8 & 17 & 11 & 17 & 10 & 10 & 16 & 1 & 2 & 4 & 0.577 \\
\hline 10 & $\begin{array}{l}\text { Blood clots finally lead to } \\
\text { death }\end{array}$ & 1 & 2 & 9 & 7 & 11 & 27 & 7 & 8 & 21 & 2 & 2 & 3 & 0.877 \\
\hline 11 & $\begin{array}{l}\text { Inflammation of the uterus } \\
\text { lining }\end{array}$ & 1 & 4 & 7 & 8 & 7 & 30 & 4 & 9 & 23 & 3 & 1 & 3 & 0.345 \\
\hline 12 & Laceration of the uterus wall & 0 & 4 & 8 & 6 & 11 & 28 & 2 & 11 & 23 & 4 & 1 & 4 & $0.010^{*}$ \\
\hline 13 & $\begin{array}{l}\text { Placenta progressing in the } \\
\text { next pregnant }\end{array}$ & 0 & 2 & 10 & 7 & 12 & 26 & 6 & 4 & 26 & 2 & 3 & 2 & 0.146 \\
\hline 14 & $\begin{array}{l}\text { Placenta permeation in the } \\
\text { next pregnant }\end{array}$ & 0 & 3 & 9 & 7 & 9 & 29 & 5 & 8 & 23 & 3 & 1 & 3 & 0.373 \\
\hline 15 & $\begin{array}{l}\text { Hysterectomy related to } \\
\text { Placenta permeation }\end{array}$ & 0 & 2 & 10 & 7 & 9 & 29 & 4 & 8 & 24 & 2 & 1 & 4 & 0.665 \\
\hline 16 & $\begin{array}{l}\text { Uterus explosion in the next } \\
\text { deliveries }\end{array}$ & 1 & 2 & 9 & 16 & 9 & 20 & 7 & 16 & 13 & 3 & 2 & 2 & $0.051^{*}$ \\
\hline
\end{tabular}

${ }^{*}$ p-value $\leq 0.05$ the significant

This table shown that laceration of the uterus wall, uterus explosion in the next deliveries, have highly significant association with the study sample age group, while the other items and the total knowledge have non- significant. Less than one third (30\%) has information about complications of Cesarean section at age (20-29 years old). 
Table (4) Association between Mothers' Knowledge toward Complications of Cesarean Section and their Level of Education

\begin{tabular}{|c|c|c|c|c|c|c|c|c|c|c|c|c|c|c|c|c|c|c|c|c|}
\hline \multirow{3}{*}{ No. } & \multirow{3}{*}{$\begin{array}{l}\text { Mothers' Knowledge toward } \\
\text { Complications of Cesarean } \\
\text { Section }\end{array}$} & \multicolumn{18}{|c|}{ Mothers' Level of Education } & \multirow{3}{*}{ P-value } \\
\hline & & \multicolumn{3}{|c|}{$\begin{array}{c}\text { No Read no } \\
\text { Write }\end{array}$} & \multicolumn{3}{|c|}{$\begin{array}{l}\text { Primary } \\
\text { level }\end{array}$} & \multicolumn{3}{|c|}{$\begin{array}{l}\text { Elementary } \\
\text { level }\end{array}$} & \multicolumn{3}{|c|}{$\begin{array}{l}\text { Secondary } \\
\text { Level }\end{array}$} & \multicolumn{3}{|c|}{$\begin{array}{l}\text { Instituted } \\
\text { Level }\end{array}$} & \multicolumn{3}{|c|}{$\begin{array}{l}\text { Collage and } \\
\text { Postgraduate } \\
\text { Level }\end{array}$} & \\
\hline & & ב & 离 & 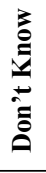 & בְ & 泀 & 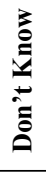 & בְב & 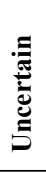 & 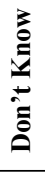 & ב & 芜 & 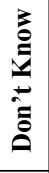 & ב & 䏤 & 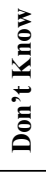 & 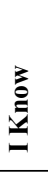 & 离 & 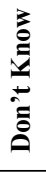 & \\
\hline 1 & $\begin{array}{l}\text { Delayed healing wound after the } \\
\text { operation }\end{array}$ & 4 & 1 & 0 & 16 & 4 & 1 & 15 & 2 & 1 & 31 & 1 & 0 & 10 & 1 & 0 & 13 & 0 & 0 & 0.479 \\
\hline 2 & $\begin{array}{l}\text { Early bleeding after the operation } \\
\text { (1 day }-14 \text { days) }\end{array}$ & 2 & 2 & 1 & 13 & 3 & 5 & 5 & 8 & 5 & 18 & 10 & 4 & 7 & 2 & 2 & 8 & 3 & 2 & 0.539 \\
\hline 3 & $\begin{array}{l}\text { Late bleeding after the operation } \\
\text { ( } 15 \text { day-40 days) }\end{array}$ & 0 & 0 & 5 & 3 & 6 & 12 & 5 & 3 & 10 & 6 & 14 & 12 & 4 & 2 & 5 & 3 & 7 & 3 & 0.096 \\
\hline 4 & Bladder puncture during operation & 0 & 0 & 5 & 3 & 5 & 13 & 1 & 5 & 12 & 5 & 8 & 19 & 3 & 1 & 7 & 8 & 1 & 4 & $0.014^{*}$ \\
\hline 5 & $\begin{array}{l}\text { Respiratory tract infection as a } \\
\text { result of anesthesia }\end{array}$ & 0 & 2 & 3 & 3 & 8 & 10 & 5 & 3 & 10 & 11 & 13 & 8 & 3 & 2 & 6 & 10 & 1 & 2 & $0.007^{*}$ \\
\hline 6 & $\begin{array}{l}\text { Weakness of a bowel movement } \\
\text { after delivery }\end{array}$ & 5 & 0 & 0 & 9 & 9 & 3 & 6 & 3 & 9 & 15 & 10 & 7 & 6 & 2 & 3 & 7 & 4 & 2 & 0.101 \\
\hline 7 & $\begin{array}{l}\text { Obesity and bulge the mother's } \\
\text { abdomen }\end{array}$ & 3 & 1 & 1 & 8 & 9 & 4 & 13 & 1 & 4 & 21 & 7 & 4 & 8 & 1 & 2 & 8 & 5 & 0 & 0.195 \\
\hline 8 & Urinary tract infection & 3 & 0 & 2 & 12 & 3 & 6 & 14 & 1 & 3 & 18 & 4 & 10 & 9 & 1 & 1 & 7 & 3 & 3 & 0.708 \\
\hline 9 & Clotting blood in lungs, and Legs. & 5 & 0 & 0 & 5 & 5 & 11 & 6 & 5 & 7 & 6 & 8 & 18 & 4 & 3 & 4 & 4 & 4 & 5 & 0.119 \\
\hline 10 & Blood clots finally lead to death & 1 & 0 & 4 & 1 & 5 & 15 & 4 & 6 & 8 & 5 & 7 & 20 & 2 & 3 & 6 & 4 & 2 & 7 & 0.651 \\
\hline 11 & Inflammation of the uterus lining & 1 & 1 & 3 & 3 & 6 & 12 & 1 & 5 & 12 & 3 & 7 & 22 & 4 & 0 & 7 & 4 & 2 & 7 & 0.373 \\
\hline 12 & Laceration of the uterus wall & 0 & 4 & 1 & 3 & 6 & 12 & 0 & 6 & 12 & 3 & 8 & 21 & 3 & 1 & 7 & 3 & 2 & 8 & 0.110 \\
\hline 13 & $\begin{array}{l}\text { Placenta progressing in the next } \\
\text { pregnant }\end{array}$ & 0 & 2 & 3 & 2 & 6 & 13 & 1 & 4 & 13 & 6 & 6 & 20 & 3 & 2 & 6 & 3 & 1 & 9 & 0.696 \\
\hline 14 & $\begin{array}{l}\text { Placenta accreta in the next } \\
\text { pregnant }\end{array}$ & 0 & 4 & 1 & 1 & 5 & 5 & 2 & 3 & 13 & 5 & 5 & 22 & 4 & 1 & 6 & 3 & 3 & 7 & $0.048^{*}$ \\
\hline 15 & $\begin{array}{l}\text { Hysterectomy related to Placenta } \\
\text { accreta }\end{array}$ & 0 & 4 & 1 & 0 & 7 & 14 & 1 & 4 & 13 & 4 & 2 & 26 & 4 & 1 & 6 & 4 & 2 & 7 & $0.001 *$ \\
\hline 16 & $\begin{array}{l}\text { Uterus explosion in the next } \\
\text { deliveries }\end{array}$ & 1 & 3 & 1 & 3 & 8 & 10 & 6 & 5 & 7 & 5 & 10 & 17 & 5 & 1 & 5 & 7 & 2 & 4 & 0.147 \\
\hline
\end{tabular}

This table shown that the association between mothers' knowledge and their level of education have significant for the items: bladder puncture during operation, respiratory tract infection as a result of anesthesia, placenta permeation in the next pregnant, and hysterectomy related to placenta permeation, while the other items and total of it have no significant association.

Table (5) the Association between Mothers' Knowledge toward Complications of Cesarean Section on her and their Multipara of Cesarean Section

\begin{tabular}{|c|c|c|c|c|c|c|c|c|}
\hline \multirow{3}{*}{ No. } & \multirow{3}{*}{$\begin{array}{l}\text { Mothers' Knowledge toward } \\
\text { Complications of Cesarean } \\
\text { Section }\end{array}$} & \multicolumn{6}{|c|}{ Mothers' Multipara of Cesarean Section } & \multirow{3}{*}{ p-Value } \\
\hline & & \multicolumn{3}{|c|}{ 2-3 times of Cesarean Section } & \multicolumn{3}{|c|}{ 4- and above times of Cesarean Section } & \\
\hline & & I Know & Uncertain & Don't Know & I Know & Uncertain & Don't Know & \\
\hline 1 & $\begin{array}{l}\text { Delayed healing wound after the } \\
\text { operation }\end{array}$ & 49 & 2 & 2 & 40 & 7 & 0 & 0.069 \\
\hline 2 & $\begin{array}{l}\text { Early bleeding after the operation } \\
\text { (1 day }-14 \text { days) }\end{array}$ & 22 & 15 & 16 & 31 & 13 & 3 & 0.606 \\
\hline
\end{tabular}




\begin{tabular}{|c|c|c|c|c|c|c|c|c|}
\hline \multirow{3}{*}{ No. } & \multirow{3}{*}{$\begin{array}{l}\text { Mothers' Knowledge toward } \\
\text { Complications of Cesarean } \\
\text { Section }\end{array}$} & \multicolumn{6}{|c|}{ Mothers' Multipara of Cesarean Section } & \multirow{3}{*}{ p-Value } \\
\hline & & \multicolumn{3}{|c|}{ 2-3 times of Cesarean Section } & \multicolumn{3}{|c|}{ 4- and above times of Cesarean Section } & \\
\hline & & I Know & Uncertain & Don't Know & I Know & Uncertain & Don't Know & \\
\hline 3 & $\begin{array}{l}\text { Late bleeding after the operation } \\
\text { ( } 15 \text { day - } 40 \text { days })\end{array}$ & 8 & 18 & 27 & 13 & 14 & 20 & 0.304 \\
\hline 4 & Bladder puncture during operation & 11 & 8 & 34 & 9 & 12 & 26 & 0.425 \\
\hline 5 & $\begin{array}{l}\text { Respiratory tract infection as a } \\
\text { result of anesthesia }\end{array}$ & 18 & 12 & 34 & 14 & 17 & 16 & 0.322 \\
\hline 6 & $\begin{array}{l}\text { Weakness of a bowel movement } \\
\text { after delivery }\end{array}$ & 23 & 18 & 12 & 25 & 10 & 12 & 0.365 \\
\hline 7 & $\begin{array}{l}\text { Obesity and bulge the mother's } \\
\text { abdomen }\end{array}$ & 32 & 11 & 10 & 29 & 13 & 5 & 0.443 \\
\hline 8 & Urinary tract infection & 32 & 9 & 12 & 31 & 3 & 13 & 0.259 \\
\hline 9 & Clotting blood in lungs, and Legs. & 17 & 13 & 23 & 13 & 12 & 22 & 0.889 \\
\hline 10 & Blood clots finally lead to death & 6 & 13 & 34 & 11 & 10 & 26 & 0.276 \\
\hline 11 & Inflammation of the uterus lining & 3 & 13 & 37 & 13 & 8 & 28 & $0.011 * * \mathrm{HS}$ \\
\hline 12 & Laceration of the uterus wall & 4 & 15 & 34 & 8 & 12 & 27 & 0.347 \\
\hline 13 & $\begin{array}{l}\text { Placenta progressing in the next } \\
\text { pregnant }\end{array}$ & 7 & 10 & 36 & 8 & 11 & 28 & 0.685 \\
\hline 14 & $\begin{array}{l}\text { Placenta accreta in the next } \\
\text { pregnant }\end{array}$ & 6 & 11 & 36 & 9 & 10 & 28 & 0.524 \\
\hline 15 & $\begin{array}{l}\text { Hysterectomy related to Placenta } \\
\text { accreta }\end{array}$ & 6 & 8 & 39 & 7 & 12 & 28 & 0.312 \\
\hline 16 & $\begin{array}{l}\text { Uterus explosion in the next } \\
\text { deliveries }\end{array}$ & 12 & 13 & 28 & 15 & 16 & 16 & 0.168 \\
\hline
\end{tabular}

${ }^{*}$ p-value $\leq 0.05$ the significant, ${ }^{* *}$ HS (High Significant)

This table shown that the association between mothers' knowledge and their multipara cesarean section has significant with Inflammation of the uterus lining, while the other items and the total have no significant association.

\section{Discussion of the Results}

In figure (1) twenty seven percent (27\%) (2-3 times) of multipara cesarean section mothers were at age (20$29)$ years old and twenty three percent $(23 \%)$ of them also have (4 and above) multipara cesarean section at age (30-39) years old this results agreed with the study by Ahmad study ${ }^{(14)}$ reported that thirty seven percent (37\%) of multipara was within age group of (21-25) years with a mean of $27 \pm 6.0$, while nearly one third $(32 \%)$ of grandmultipara was within age group 36-40 years with a mean of $33.2 \pm 6.1$. Also $^{(15)}$ reported that the average age of the study group was 25.1 years, which was a suitable age for reproduction. Simonsin study ${ }^{(16)}$ reported that numerous obstetrics complications have been independently associated with progressive maternal age. In addition, older women with 5 or more babies known as risk group. ${ }^{(17)}$ Daniel and Seidman ${ }^{(18)}$ considered the age factors that increase the hazards of high parity, so the grandmultipara is an older woman and suffers those disabilities which accompany age; especially her cardiovascular system is less resilient so that hypertensive disease is more manifest. The risks of teenage pregnancy are well known, but these account for a relatively small proportion of pregnancies in most countries. In contrast, the proportion of pregnancies in women aged 35 and older are higher and are rising in many countries. The proportions of older mother are rising in many countries ranged from a low of 7.5 in Slovakia to a high of 24.3 in Ireland. ${ }^{(19)}$ Older mothers have a higher prevalence of pregnancy complications, including some congenital anomalies, hypertension, and diabetes. Older maternal ages is significant risk factor for maternal mortality and morbidity, are more delivered by $\mathrm{C} / \mathrm{S}$. and have more low birth weights, which will thus cause higher rates of fetal and infant death. ${ }^{(20)}$

Educational level concerning poor educational status of women largely contributes to multipara cesarean section (MCS) and its complications, and prevents 
them to take benefit from available facilities. That is why MCS is more common in lower socioeconomic group. ${ }^{(21)}$ The educational level for most mothers in both groups (2-3, and 4-and above) times (MCS) was limited (secondary and primary educational level graduate) as shown in figure (2). This result agrees with Ahmed and Roman et al. ${ }^{(14}$ and 22$)$ studies who stated in their study that concerning obstetric and neonatal outcomes in grand multiparity that grand multipara was in lower level of education, and consistent with Begum study ${ }^{(23)}$ who reported that the level of education status almost poor in grand multiparous women. Mothers of poor level of education often face the following consequences: social isolation, poor life habits, low education level, maltreatment, stress, and depression, in addition young mothers are at greater risk of leaving school or attaining a lower level of education. ${ }^{(24)}$ Educational level is well correlated with perinatal outcome. ${ }^{(20)}$

The results indicated that more than two third of mothers $(89 \%)$ have information about delayed healing wound after operation and more than half (53\%) knowing about bleeding after the operation, more than one third (48\%) weakness of bowel movement after delivery, more than one half $(61 \%$, and $63 \%)$ about obesity and bulge their abdomen, and knowing about urinary tract infection after cesarean section and this results agree with Ghasvari, et al. study ${ }^{(25)}$ indicate mothers have good and moderate knowledge about maternally complication for elective and emergency cesarean section.

In table (3) shows that no significant association between maternal knowledge and their age groups, and its agree with Ghasvari and et al. study ${ }^{(25)}$.

In regard to their Educational Level study by Ghasvari and et al. ${ }^{(25)}$ reported that have $35.5 \%$ and $41.8 \%$ ) good and moderate knowledge level about cesarean section at under diploma mothers educational level and its agree with the present study in tables (4), while the association between mothers' knowledge and their level of education have significant for the items: bladder puncture during operation, respiratory tract infection as a result of anesthesia, placenta accreta in the next pregnant, and hysterectomy related to placenta accreta only.

Related to their multipara cesarean section the present study table (5) shown that the association between mothers' knowledge and their multipara cesarean section has significant with Inflammation of the uterus lining item only and the other items and totally knowledge items has no significant and it's agree with Ghasvariand et al. ${ }^{(25)}$ reported that have $(33.9 \%$ and $43.5 \%)$ good and moderate level of knowledge.

\section{Conclusion}

Most of the study samples have multipara cesarean section at age above thirty years old; means the previous twenty years increase number of cesarean section instead of normal vaginal delivery. Most of them have low educational level lead to poor information about the risk of cesarean section and chose easily kind of delivery with no difficulty pain.

Financial Disclosure: There is no financial disclosure.

Conflict of Interest: None to declare.

Ethical Clearance: All experimental protocols were approved under the Al-Bayan University and all experiments were carried out in accordance with approved guidelines.

\section{References}

1. Lee YM, D'Alton ME. Cesarean delivery on maternal request: The impact on mother and newborn. ClinPerinatol 2008; 35: 505-518.

2. Gunnervik C, Sydsjo G, Sydsjo A, Selling KE, Josefsson A. Attitudetowards cesarean section in a nationwide sample of obstetrician and gynecologists. ActaObstetGynecolScand 2008; 87: 438-444.

3. Zhang J, Liu Y, Maikle S, Zheng J, Sun W, Li Z. Cesarean delivery on maternal request in southeast China. ObstetGynecol 2008; 111: 1077-1082.

4. Ali Mohamadian M, Shriat M, Mahmoudi M. The effect of pregnant women's request on elective cesarean section rate. Payesh 2003; 2: 133-139.

5. Wax J. Maternal request cesarean versus planned spontaneous vaginal delivery: Maternal morbidity and short term outcomes. SeminPerinatol 2006; 30: 247-252.

6. Miller D, Chollet JA, Goodwin TM. Clinical risk factors for placenta previa-placenta accreta. Am J ObstetGynecol 1997; 177: 210-214.

7. Wu S, Kocherginsky M, Hibbard JU. Abnormal placentation: Twenty-year analysis. Am J ObstetGynecol 2005; 192: 1458- 1461. 
8. Jain L, Dudel G. Respiratory transition in infants delivered by cesarean section. Semin Perinatol 2006; 30: 296-304.

9. Oyelese Y, Simulian JC. Placenta previa, placenta accreta, and vasa previa. Obstet Gynecol 2006; 107: 927-941.

10. Rotas M, Haberman S, Levgur M. Cesarean scar ectopic pregnancies: Etiology, diagnosis, and management. Obstet Gynecol 2006; 107: 13731381.

11. Motamedi B, Janghorbanian $\mathrm{M}$, Eftekhari N. Prevalence of cesarean section and some determinant factors in Kerman. J Guilan Univ Med Sci 2000; 9: 88-96.

12. Norman B,Crowhurst J, Plaat F. Elective cesarean on request. All type of anesthesia carry risks. BMJ. 1999; 318: 120.

13. Armson B. Is planned cesarean childbirth a safe alternative? CMAJ 2007; 176: 475-476.

14. Jaleel A. Maternal risks in antenatal, intranatal, postnatal and its impact on pregnancy outcomes in grandmultiparous women; a thesis submitted in Uni. of Baghdad, Coll. Of Nursing, 2010.

15. Martin J, Hamilton B. Births: final data for 2002, National Statistics Reports, 2003; 52 (10): 1-114.

16. Simonsen, Sara M .; Effect of Grandmultiparity on young women, Obstetrics \& Gynecology, 2005; 106, Issue 3: 454-460.
17. Heffner L. How Much Dose Parity Matter? Obstetrics \& Gynecology, 2005; 106(3): 444 - 445.

18. Daniel S. Are multiple cesarean sections safe? European Journal of Obstetrics \& Gynecology and Reproductive Biology. 1994; 57: 7-12.

19. Clearly G. Impact of Maternal Age on Obstetric Outcome. The American College of Obstetricians and Gynecologists. 2005; 105(5).

20. European Perinatal Health Report, is available in www. Europeristat. Com. 2008.

21. Houqe M, Houqe E. Pregnancy Complications of grandmultiparity at a rural setting of south Africa, Iranian Journal of Reproductive Medicene, 2008; 6 (1): 25-31

22. Roman H, Verspyck E, Hulsey $T$, Marpeau L, Barau G. obstetric \& neonatal outcome in grandmultiparity, Obstetrics \& Gynecology, 2004; 103 (6) : 9-1294.

23. Begum S. Age \& Parity related problems affecting outcome of labor in grandmultiparas, Pakistan Journal Med. Res., 2003; 42 (4): 1-6.

24. Obah R. effect of Teenage pregnancy, eden Newspaper, is available in http://www.eden newspaper. Com/index. Php? 2010.

25. Ghasoari M, Rahmanian U, Rahmanian K. Knowledge of pregnant women in the Southwest Iran about complications of cesarean section; J. Jahrom Univ. Med. Sci. 2012; 10(2):31-5. 